\title{
MENGOPTIMALKAN BIAYA DISTRIBUSI PAKAN TERNAK DENGAN MENGGUNAKAN METODE TRANSPORTASI (Studi Kasus di PT. $X$ Krian)
}

\author{
Ika Widya Ardhyani \\ Teknik Industri, Fakultas Teknik \\ Universitas Maarif Hasyim Latif, Sidoarjo, Indonesia \\ e-mail: ika_widya@dosen.umaha.ac.id
}

Diterima: 1 Nopember 2017. Disetujui : 25 Nopember 2017. Dipublikasikan : 4 Desember 2017

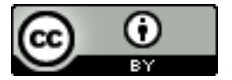

(C)2017 -TESJ Fakultas Teknik Universitas Maarif Hasyim Latif. Ini adalah artikel dengan akses terbuka di bawah lisensi CC BY 4.0 (https://creativecommons.org/licenses/by/4.0/)

\begin{abstract}
ABSTRAK
Metode transportasi adalah metode yang digunakan untuk mengatur distribusi dari sumber-sumber yang menyediakan produk yang sama ke tempat-tempat yang membutuhkan secara optimal. Alokasi produk ini harus diatur sedemikian rupa, karena terdapat perbedaan biaya-biaya alokasi dari satu sumber ke suatu tempat tujuan. Kasus transportasi timbul ketika suatu perusahaan mencoba menentukan cara pengiriman (distribusi) suatu jenis barang (item) dari beberapa sumber (lokasi penawaran) ke beberapa tujuan (lokasi permintaan) yang dapat meminimalkan biaya. PT. $X$ dihadapkan pada pemasalahan semakin tingginya biaya pemasaran karena kurang teraturnya pola pendistribusian dari tempat sumber ke tempat tujuan pemasaran, sehingga perusahaan berusaha untuk mengoptimalkan biaya transportasi yang dikeluarkan. Hal ini, jika di biarkan dapat mengakibatkan kerugian bagi perusahaan. Metode analisa data yang digunakan untuk memecahkan masalah tersebut menggunakan metode transportasi, untuk solusi awal menggunakan metode pojok kiri atas pojok kanan bawah (North West Corner Method), ongkos terkecil (Least Cost Method), VAM (Vogel's Approximation Method) dan uji optimal menggunakan metode batu loncatan (Stepping Stone Method) dan MODI (Modified Distribution). Pendistribusian produk pakan ternak di PT. $X$ dengan menggunakan metode transportasi didapatkan hasil yang optimal. Total biaya transportasi untuk solusi awal menggunakan metode pojok kiri atas pojok kanan bawah (North West Corner Method) = Rp. 43.118.639.196,-; ongkos terkecil (Least Cost Method) = Rp. 43.094.262.979,-; VAM (Vogel's Approximation Method) = Rp. 43.089.578.434,- dan uji optimal menggunakan metode batu loncatan (Stepping Stone Method) dan MODI (Modified Distribution) didapatkan hasil yang optimal adalah : Rp. 43.087.656.564,--
\end{abstract}

Kata kunci: metode transportasi; NWC, ongkos terkecil, VAM, batu loncatan dan MODI.

\section{PENDAHULUAN}

Persoalan transportasi yang sering muncul dalam kehidupan sehari-hari, merupakan golongan tersendiri dalam persoalan program liniear. Metode transportasi juga dapat digunakan untuk menyelesaikan beberapa persoalan optimasi. Persoalan transportasi berkenaan dengan pemilihan rute (jalur) pengangkutan yang mengakibatkan biaya total dari pengangkutan minimum.

Metode transportasi adalah metode yang digunakan untuk mengatur distribusi dari sumbersumber yang menyediakan produk yang sama ke tempat-tempat yang membutuhkan secara optimal. Alokasi produk ini harus diatur sedemikian rupa, karena terdapat perbedaan biaya-biaya alokasi dari satu sumber ke suatu tempat tujuan.
Pada dasarnya suatu perusahaan, baik itu perusahaan yang bergerak dibidang industri jasa maupun manufacturing selalu berusaha menjamin kelancaran, kelangsungan hidup dan pertumbuhan, baik jangka panjang maupun jangka pendek perusahaan, walaupun perusahaan mempunyai banyak tujuan yang harus dicapai, tetapi pada dasarnya tujuan utama perusahaan adalah mendapatkan keuntungan yang semaksimal mungkin.

Kasus transportasi timbul ketika suatu perusahaan mencoba menentukan cara pengiriman (distribusi) suatu jenis barang (item) dari beberapa sumber (lokasi penawaran) ke beberapa tujuan (lokasi permintaan) yang dapat menimimumkan biaya. Sasaran dalam persoalan transportasi di PT. $X$ ini adalah mengalokasikan barang (produk pakan) yang ada pada sumber sedemikian rupa hingga terpenuhi semua 
kebutuhan pada tujuan (lokasi permintaan). PT. $X$ yang dihadapkan pada pemasalahan semakin tingginya biaya pemasaran karena tidak teraturnya pola pendistribusian dari tempat sumber ke tempat tujuan pemasaran, sehingga perusahaan berusaha untuk mengoptimalkan biaya transportasi yang dikeluarkan. Hal ini, jika di biarkan dapat mengakibatkan kerugian bagi perusahaan.

Berdasarkan keadaan inilah maka dalam penelitian ini mencoba untuk mencari solusi dengan pemilihan rute (jalur) pengangkutan atau pendistribusian yang mengakibatkan biaya total dari pengangkutan atau pendistribusian tersebut optimum. Dalam hal menentukan suatu rute pendistribusian yang tepat dapat digunakan suatu metode transportasi dalam program liniear.

\section{METODE PENELITIAN}

Penelitian ini dilakukan atas beberapa tahap, yaitu tahap identifikasi dan perumusan masalah, penentuan tujuan penelitian serta tahap analisa data.

\section{Tahap Identifikasi dan Perumusan Masalah}

Pada tahap ini peneliti menentukan topik penelitian serta masalah yang diangkat dan diteliti berdasarkan kondisi yang ada di PT. $X$ wilayah Krian yaitu mengidentifikasi masalah apa yang dihadapi oleh perusahaan. Kemudian merumuskan masalah mengenai cara untuk mengoptimalkan biaya pendistribusian pakan komplit butiran ayam pedaging.

Penelitian dilakukan di PT. $X$ yang belokasi di Krian, Sidoarjo, Jawa Timur. Penelitian difokuskan pada masalah pendistribusian produk pakan ternak yaitu pakan komplit butiran ayam pedaging.

\section{Tahap Penentuan Tujuan Penelitian}

Pada tahap ini ditentukan tujuan atau arah dari penelitian yang dilakukan sehubungan dengan permasalahan yang telah diangkat, yaitu mengetahui biaya yang optimal dalam pendistribusian produk pakan komplit butiran ayam pedaging di PT. $X$ wilayah Krian.

\section{Tahap Analisa Data}

Pada tahap ini dilakukan analisa data yang merupaka proses perhitungan secara kuantitatif dengan menggunakan perumusan yang telah ditentukan sebagai penganalisa data yang sesuai dengan masalah yang ada.

Adapun langkah-langkah dalam menyelesaikannya adalah sebagai berikut: (1) menentukan solusi fisibel awal dan (2) melakukan uji optimalitas

\section{Menentukan Solusi Fisibel Awal}

Solusi fisibel awal adalah suatu solusi untuk mencari suatu pengalokasian distribusi barang yang mungkin dari tiap sumber ke tiap tujuan. Dalam penelitian ini solusi fisibel awal digunakan dengan metode pojok kiri atas pojok kanan bawah (North West Corner Method), metode ongkos terkecil (Least Cost Method), dan VAM (Vogel's Approximation Method).

\section{Metode pojok kiri atas pojok kanan bawah (North West Corner Method)}

Metode ini adalah metode yang paling sederhana diantara metode untuk mencari solusi awal, karena tidak mempertimbangkan biaya transportasi (Siagian; 1987; 159). Algoritma metode pojok kiri atas pojok kanan bawah (North West Corner Method) untuk mencapai solusi fisibel awal dari masalah transportasi adalah sebagai berikut :

1. Memulai dari pojok barat laut alokasikan sebesar $X_{11}=\min \left(a_{1}, b_{1}\right)$.

- Bila $a_{1}>b_{1}$, maka $X_{11}=b_{1}$. Teruskan ke sel $(1,2)$ yaitu gerakan mendatar dimana $X_{12}=$ $\min \left(a_{1}-b_{1}, b_{2}\right)$.

- Bila $a_{1}<b_{1}$, maka $X_{11}=a_{1}$. Teruskan ke sel $(2,1)$ yaitu gerakan tegak dimana $X_{21}=\min$ $\left(b_{1}-a_{1}, a_{2}\right)$.

- Bila $a_{1}=b_{1}$, maka buatlah $X_{11}=a_{1}=b_{1}$ dan gerakan teruskan ke $X_{12}$ (gerakan miring).

2. Meneruskan langkah ini, sehingga mendekati pojok barat laut hingga akhirnya sampai semua penawaran telah dihabiskan dan keperluan permintaan telah terpenuhi.

\section{Metode ongkos terkecil \\ (Least Cost Method)}

Algoritma metode ongkos terkecil (Least Cost Method) untuk mencapai solusi fisibel awal dari masalah transportasi adalah sebagai berikut :

1. Menyusun tabel awal yang berisi tabel biaya transportasi.

2. Mencari sel yang memiliki biaya terkecil $C_{i j}$ pada tabel awal.

3. Pada $C_{i j}$ terkecil dialokasikan sebanyak mungkin tanpa melanggar batasan-batasannya. Mengisi $X_{i j}=\min \left(a_{i}, b_{j}\right)$.

- Jika $b_{j}<a_{i}$ maka $X_{i j}=b_{j}$ kolom ke $j$ tidak diperhitungkan lagi dan $a_{i}$ berkurang sebesar $b_{j}$.

- Jika $b_{j}>a_{i}$ maka $X_{i j}=a_{i}$ baris ke $i$ tidak diperhitungkan lagi dan $b_{j}$ berkurang sebesar $a_{i .}$

- Jika $b_{j}=a_{i}$ maka $X_{i j}=a_{i}=b_{j}$ baris ke $i$ dan kolom ke $j$ tidak diperhitungkan lagi.

4. Mencari sel yang memiliki $C_{i j}$ terkecil, dilanjutkan dengan cara yang sama sampai semua persediaan habis dan permintaan terpenuhi. 


\section{Metode VAM (Vogel's Approximation Method)}

Algoritma metode VAM (Vogel's Approximation Method) untuk mencapai solusi fisibel awal dari masalah transportasi adalah sebagai berikut :

1. Menyusun kebutuhan, kapasitas masing-masing sumber dan biaya pengangkutan kedalam matriks.

2. Mencari selisih biaya terkecil dengan biaya terkecil berikutnya untuk setiap kolom maupun baris.

3. Memilih selisih biaya terbesar dan mengalokasikan produk sebanyak mungkin ke sel yang memiliki biaya terkecil.

4. Menghilangkan baris atau kolom yang sudah diisi sepenuhnya karena tidak mungkin diisi lagi.

5. Menentukan kembali perbedaan (selisih) biaya pada langkah 2 untuk kolom dan baris yang belum terisi. Ulangi langkah 3 sampai dengan langkah 5, sampai semua kolom dan baris teralokasi.

6. Setelah terisi semua, kemudian menghitung biaya transportasi secara keseluruhan.

7. Melakukan Uji Optimalitas

\section{Melakukan Uji Optimalitas}

Setelah diperoleh solusi fisibel awal maka langkah selanjutnya adalah melakukan uji optimalitas. Langkah ini merupakan langkah penyelesaian model untuk mendapatkan solusi minimal. Pada penelitian ini pengujian optimalitas digunakan dengan menggunakan metode batu loncatan (Stepping Stone Method) dan MODI (Modified Distribution).

\section{Metode batu loncatan}

\section{(Stepping Stone Method)}

Algoritma dari metode batu loncatan bisa dituliskan sebagai berikut :

1. Tes kemerosotan, yaitu menghitung banyaknya sel basis pada solusi basis awal. Jika banyaknya sel basis kurang dari $m+n-1$ maka terjadi kemerosotan.

2. Menghitung harga $U_{i}$ dan $V_{j}$ untuk semua sel basis menggunakan persamaan $U_{i}+V_{j}=C_{i j}$. Sebelumnya ditentukan salah satu dari $U_{i}$ atau $V_{j}$ berharga nol.

3. Menghitung nilai perubahan biaya untuk setiap sel non basis dinyatakan dengan $D_{i j}$ menggunakan persamaan: $D_{i j}=C_{i j}-U_{i}-V_{i}$.

4. Apabila seluruh harga $D_{i j}$ sudah lebih besar atau sama dengan nol maka solusi sudah optimal, jika sebaliknya harus dilakukan evaluasi ulang yaitu memilih $X_{i j}$ dengan nilai $D_{i j}$ paling negatif (negatif dengan nilai paling besar) sebagai entering variable. Pengalokasian barang pada entering variable mengikuti aturan jalur tertutup.

5. Langkah (2) sampai (4) diulang hingga nilai $D_{i j} \geq 0$.
Secara garis besar pembuatan jalur tertutup sebagai berikut:

- Menentukan sel basis yang akan dihitung nilai $Z_{i j}-C_{i j}$

- Sel non basis dengan sel basis yang mempunyai pasangan pada kolom yang sama dihubungkan. Begitu seterusnya sambung-menyambung sampai kembali ke sel non basis lagi.

- Harga semua sel-sel yang dilalui jalur dengan membuat tanda berganti-ganti dari positif $(+)$ ke negatif (-) dimulai dari sel basis.

Tujuan dari pembuatan jalur ini adalah untuk mempertahankan kendala persediaan dan permintaan sambil melakukan alokasi ulang ke sel non basis. Beberapa hal penting yang berkaitan dengan penyusunan jalur tetutup adalah :

- Arah yang diambil, baik searah maupun berlawanan arah dengan jarum jam adalah tidak penting.

- Hanya ada satu jalur tertutup untuk setiap sel non basis.

- Pengurangan dan penambahan harus sama besar antara basis dan kolom pada jalur itu.

Sel non basis dengan nilai $Z_{i j}-C_{i j}$ paling negatif (negatif dengan nilai terbesar) dipilih untuk dievaluasi. Sel non basis yang terpilih harus masuk basis menggantikan sel basis yang mempunyai nilai terkecil. Sel yang keluar dari sel basis nilainya menjadi nol pada tabel berikutnya, sedangkan sel yang masuk basis bernilai sama dengan nilai sel yang keluar basis. Sel yang biayanya mempunyai tanda negatif $(-)$, nilai variabelnya dikurangi, sedangkan yang bertanda positif (+) nilai variabelnya ditambah dengan nilai terkecil yang dipilih. Cara ini diulang terus-menerus sampai nilai $Z_{i j}-C_{i j} \geq 0$ yang menandakan penyelesaian sudah optimal.

\section{MODI (Modified Distribution)}

Algoritma dari Metode MODI (Modified Distribution) bisa dituliskan sebagai berikut:

1. Menentukan tabel awal yang fisibel dengan menggunakan metode $N W$ - Corner atau metode ongkos terkecil.

2. Menambahkan variabel $R_{i}$ dan $K_{j}$ pada setiap baris dan kolom.

3. Mencari nilai $R_{i}$ maupun $K_{j}$ untuk setiap sel basis dengan menggunakan rumus : $R_{i}+K_{j}=C_{i j}$ dengan memisahkan salah satu nilai $R_{i}$ atau $K_{j}$ sama dengan nol.

4. Menghitung semua nilai sel bukan basis dengan menggunakan rumus $C_{i j}-R_{i}-K_{i}$.

5. Menentukan sel yang akan masuk basis dengan memilih nilai sel bukan basis yang memiliki nilai negatif terbesar. Kemudian membuat closed path untuk menentukan sel yang akan keluar 
dengan memilih jumlah unit terkecil dari sel yang bertanda negatif.

6. Tabel optimum tercapai apabila sel bukan basis semuanya memiliki nilai $=0$.

7. Jika tabel belum optimum, kembali ke langkah 2 sehingga ditemukan tabel optimum.

\section{HASIL DAN PEMBAHASAN}

\section{Pengambilan Data}

Data yang diambil dalam penelitian ini merupakan data sekunder. Adapun data perusahaan yang digunakan dalam penelitian ini adalah:

1. Jumlah dan Lokasi Sumber (pabrik)

PT. X memiliki tiga pabrik di area Jawa Tengah dan Jawa Timur yaitu pabrik 1 yang terletak di daerah Krian, pabrik 2 di daerah Kediri dan pabrik 3 di daerah Semarang. Ketiga pabrik tersebut memproduksi produk pakan unggas dan babi, dimana salah satu produk ketiga pabrik adalah pakan komplit butiran ayam pedaging. Tabel 1 menunjukkan data pendistribusian produk pakan komplit butiran ayam pedaging pada bulan Agustus 2010.

Tabel 1 Jumlah produk pakan yang di distribusikan bulan agustus 2010

\begin{tabular}{|l|c|r|}
\hline \multicolumn{2}{|l|}{ Lokasi pabrik } & Jumlah produk pakan $(\mathrm{Kg})$ \\
\hline Krian & $\mathrm{P}_{1}$ & 17.927 .552 \\
\hline Kediri & $\mathrm{P}_{2}$ & 13.149 .384 \\
\hline Semarang & $\mathrm{P}_{3}$ & 11.530 .212 \\
\hline \multicolumn{2}{|r|}{ Total } & 42.607 .148 \\
\hline
\end{tabular}

2. Jumlah dan Lokasi Tujuan (pemasaran)

PT. X mendistribusikan produk butiran ayam pedaging ke lima daerah pemasaran yaitu Blitar, Tulungaggung, Kediri, Banyuwangi, dan Solo. Adapun Tabel 2 memperlihatkan jumlah permintaan dan lokasi daerah pemasaran bulan Agustus 2010.

Tabel 2 Jumlah permintaan produk pakan bulan Agustus 2010

\begin{tabular}{|l|r|r|}
\hline Daerah pemasaran & Jumlah permintaan produk pakan (Kg) \\
\hline Blitar & A & 15.786 .133 \\
\hline Tulungagung & B & 5.705 .559 \\
\hline Kediri & C & 6.963 .037 \\
\hline Banyuwangi & D & 10.429 .782 \\
\hline Solo & E & 3.722 .637 \\
\hline \multicolumn{2}{|r|}{ Total } & 42.607 .148 \\
\hline
\end{tabular}

3. Biaya Produksi dan Transportasi

Biaya produksi untuk masing-masing pabrik besarnya sama yaitu Rp. 1.000,-/kg, sedangkan biaya transportasi per kg dari sumber (pabrik) ke tempat tujuan (pemasaran) dapat dilihat dalam Tabel 3.

Tabel 3 Biaya transportasi per kg (dalam rupiah)

\begin{tabular}{|l|c|c|c|c|c|}
\hline \multirow{2}{*}{ Pabrik } & \multicolumn{5}{|c|}{ Daerah Pemasaran } \\
\cline { 2 - 6 } & Blitar & Tulungagung & Kediri & Banyuwangi & Solo \\
\hline Krian & 9.8 & 9.7 & 9.2 & 14.7 & 14 \\
\hline Kediri & 8.3 & 13.2 & 7.4 & 15.7 & 12.4 \\
\hline Semarang & 15.3 & 14.9 & 14.3 & 20.8 & 9.1 \\
\hline
\end{tabular}

Keterangan :

Biaya transportasi/kg = biaya bahan bakar kendaraan/kg + biaya pegawai (sopir, pembantu sopir)/kg

\section{Perhitungan dengan Metode Transportasi}

1. Menentukan solusi fisibel awal

Solusi fisibel basis awal adalah suatu solusi untuk mencari suatu pengalokasian distribusi barang yang mungkin dari tiap sumber ketiap tujuan. Dalam penelitian ini solusi fisibel awal yang digunakan adalah dengan metode pojok kiri atas pojok kanan bawah (Noth West Corner Method), metode ongkos terkecil (Least Cost Method) dan metode pendekatan vogel (Vogel's Approximation Method, VAM ).

2. Melakukan Uji Optimalisasi

Setelah diperoleh solusi fisibel awal maka langkah selanjutnya adalah melakukan uji optimalisasi. Langkah ini merupakan langkah penyelesaian model untuk mendapatkan solusi optimum, pada penelitian ini pengujian optimalisasi dilakukan dengan metode batu loncatan (Stepping Stone Method) dan MODI (Modified Distribusion Method).

Berdasarkan dari pengolahan dan analisa data dengan metode transportasi dimana penyelesaian awal menggunakan metode pojok kiri atas pojok kanan bawah (North West Corner Method), ongkos terkecil (Least Cost Method), dan VAM (Vogel's Approximation Method) kemudian malakukan uji optimalisasi dengan menggunakan metode batu loncatan (Stepping Stone Method) dan MODI (Modified Distribution), diperoleh hasil sebagai berikut :

\section{Penyelesaian awal dengan hasil}

a. Metode pojok kiri atas pojok kanan bawah (North West Corner Method), hasilnya adalah Rp. 43.118.639.196,-. Dengan kegiatan pendistribusian sebagai berikut :

- Kegiatan pengiriman / pendistribusian pakan dari pabrik Krian $\left(\mathrm{P}_{1}\right)$ ke 2 daerah pemasaran, yaitu Blitar (A) sebesar 15.786.133 kg, dan Tulungagung (B) sebesar $2.141 .419 \mathrm{~kg}$.

- Kegiatan pengiriman / pendistribusian pakan dari pabrik Kediri $\left(\mathrm{P}_{2}\right)$ ke 3 daerah pemasaran, yaitu Tulungagung (B) sebesar 3.564.140 kg, Kediri (C) sebesar 6.963.037 kg dan Banyuwangi (D) sebesar 2.622.207 kg.

- Kegiatan pengiriman / pendistribusian pakan dari pabrik Semarang $\left(\mathrm{P}_{3}\right)$ ke 2 daerah 
pemasaran, yaitu Banyuwangi (D) sebesar 7.807.575 kg dan Solo (E) sebesar 3.722.637 $\mathrm{kg}$.

b. Metode ongkos terkecil (Least Cost Method), hasilnya adalah Rp. 43.094.262.979,-. Dengan kegiatan pendistribusian sebagai berikut :

- Kegiatan pengiriman / pendistribusian pakan di pabrik Krian $\left(\mathrm{P}_{1}\right)$ ke 3 daerah pemasaran yaitu Blitar sebesar $9.599 .786 \mathrm{~kg}$, Tulungagung (B) sebesar $5.705 .559 \mathrm{~kg}$ dan Banyuwangi (D) sebesar $2.622 .207 \mathrm{~kg}$.

- Kegiatan pengiriman / pendistribusian pakan dari pabrik Kediri $\left(\mathrm{P}_{2}\right)$ ke 2 daerah pemasaran yaitu Blitar (A) sebesar 6.186.347 kg dan Kediri (C) sebesar 6.963 .037 kg.

- Kegiatan pengiriman / pendistribusian pakan dari pabrik Semarang $\left(\mathrm{P}_{3}\right)$ ke 2 daerah pemasaran, yaitu Banyuwangi sebesar $7.807 .575 \mathrm{~kg}$ dan Solo sebesar $3.722 .637 \mathrm{~kg}$.

c. Metode VAM (Vogel's Approximation Method) hasilnya adalah Rp. 43.089.578.434,-. Dengan kegiatan pendistribusian sebagai berikut :

- Kegiatan pengiriman / pendistribusian pakan di pabrik Krian $\left(\mathrm{P}_{1}\right)$ ke 3 daerah pemasaran yaitu Blitar sebesar $1.792 .211 \mathrm{~kg}$, Tulungagung (B) sebesar $5.705 .559 \mathrm{~kg}$ dan Banyuwangi (D) sebesar $10.429 .782 \mathrm{~kg}$.

- Kegiatan pengiriman / pendistribusian pakan dari pabrik Kediri $\left(\mathrm{P}_{2}\right)$ ke 2 daerah pemasaran yaitu Blitar (A) sebesar 6.186.347 kg dan Kediri (C) sebesar 6.963 .037 kg.

- Kegiatan pengiriman / pendistribusian pakan dari pabrik Semarang $\left(\mathrm{P}_{3}\right)$ ke 2 daerah pemasaran, yaitu Blitar sebesar $7.807 .575 \mathrm{~kg}$ dan Solo sebesar $3.722 .637 \mathrm{~kg}$.

\section{Uji optimalisasi dengan hasil}

a. Metode batu loncatan (Stepping Stone Method) berdasarkan tabel pojok kiri atas pojok kanan bawah (North West Corner Method), hasil biaya yang paling optimal adalah : Rp. 43.087.656.564,-. Dengan kegiatan pendistribusian sebagai berikut:

- Dari pabrik 1 (Krian) ke daerah A (Blitar) $7.497 .770 \mathrm{~kg}$.

- Dari pabrik 1 (Krian) ke daerah D (Banyuwangi) $10.429 .782 \mathrm{~kg}$.

- Dari pabrik 2 (Kediri ) ke daerah A (Blitar) $8.288 .363 \mathrm{~kg}$.

- Dari pabrik 2 (Kediri ) ke daerah C (Kediri) $4.861 .021 \mathrm{~kg}$.

- Dari pabrik 3 (Semarang) ke daerah B (Tulungagung) $5.705 .559 \mathrm{~kg}$.

- Dari pabrik 3 (Semarang) ke daerah C (Kediri) $2.102 .016 \mathrm{~kg}$.

- Dari pabrik 3 (Semarang) ke daerah E (Solo) $3.722 .637 \mathrm{~kg}$. b. Metode batu loncatan (Stepping Stone Method) berdasarkan tabel metode ongkos terkecil (Least Cost Method), hasil biaya yang paling optimal adalah: Rp. 43.087.656.564,-. Dengan kegiatan pendistribusian sebagai berikut :

- Dari pabrik 1 (Krian) ke daerah A (Blitar) $7.497 .770 \mathrm{~kg}$.

- Dari pabrik 1 (Krian) ke daerah D (Banyuwangi) $10.429 .782 \mathrm{~kg}$.

- Dari pabrik 2 (Kediri ) ke daerah A (Blitar) $8.288 .363 \mathrm{~kg}$.

- Dari pabrik 2 (Kediri) ke daerah C (Kediri) $4.861 .021 \mathrm{~kg}$.

- Dari pabrik 3 (Semarang) ke daerah B (Tulungagung) $5.705 .559 \mathrm{~kg}$.

- Dari pabrik 3 (Semarang) ke daerah C (Kediri) $2.102 .016 \mathrm{~kg}$.

- Dari pabrik 3 (Semarang) ke daerah E (Solo) $3.722 .637 \mathrm{~kg}$.

c. Metode batu loncatan (Stepping Stone Method) berdasarkan tabel VAM (Vogel's Approximation Method), hasil biaya yang paling optimal adalah:Rp. 43.087.656.564,-. Dengan kegiatan pendistribusian sebagai berikut :

- Dari pabrik 1 (Krian) ke daerah A (Blitar) $7.497 .770 \mathrm{~kg}$.

- Dari pabrik 1 (Krian) ke daerah D (Banyuwangi) $10.429 .782 \mathrm{~kg}$.

- Dari pabrik 2 (Kediri ) ke daerah A (Blitar) $8.288 .363 \mathrm{~kg}$.

- Dari pabrik 2 (Kediri) ke daerah C (Kediri) $4.861 .021 \mathrm{~kg}$

- Dari pabrik 3 (Semarang) ke daerah B (Tulungagung) $5.705 .559 \mathrm{~kg}$.

- Dari pabrik 3 (Semarang) ke daerah C (Kediri) $2.102 .016 \mathrm{~kg}$.

- Dari pabrik 3 (Semarang) ke daerah E (Solo) $3.722 .637 \mathrm{~kg}$.

d. Metode MODI (Modified Distribution) berdasarkan tabel metode pojok kiri atas pojok kiri bawah (North West Corner Method), hasil biaya yang paling optimal adalah : Rp. 43.087.656.564,-. . Dengan kegiatan pendistribusian sebagai berikut:

- Dari pabrik Krian ( $\mathrm{P}_{1}$ ) ke daerah A (Blitar) $7.497 .770 \mathrm{~kg}$.

- Dari pabrik Krian $\left(\mathrm{P}_{1}\right)$ ke daerah D ( Banyuwangi) $10.429 .782 \mathrm{~kg}$.

- Dari pabrik Kediri $\left(\mathrm{P}_{2}\right)$ ke daerah A (Blitar) $8.288 .363 \mathrm{~kg}$.

- Dari pabrik Kediri $\left(\mathrm{P}_{2}\right)$ ke daerah C ( Kediri ) $4.861 .021 \mathrm{~kg}$.

- Dari pabrik Semarang $\left(\mathrm{P}_{3}\right)$ ke daerah B (Tulungagung) $5.705 .559 \mathrm{~kg}$.

- Dari pabrik Semarang $\left(\mathrm{P}_{3}\right)$ ke daerah $\mathrm{C}$ (Kediri) $2.102 .016 \mathrm{~kg}$.

- Dari pabrik Semarang $\left(\mathrm{P}_{3}\right)$ ke daerah E (Solo) $3.722 .637 \mathrm{~kg}$. 
e. Metode MODI (Modified Distribution) berdasarkan tabel metode ongkos terkecil (Least Cost Method), hasil biaya yang paling optimal adalah: Rp. 43.087.656.564,--. Dengan kegiatan pendistribusian sebagai berikut :

- Dari pabrik Krian $\left(\mathrm{P}_{1}\right)$ ke daerah A (Blitar) $7.497 .770 \mathrm{~kg}$.

- Dari pabrik Krian $\left(\mathrm{P}_{1}\right)$ ke daerah D (Banyuwangi) $10.429 .782 \mathrm{~kg}$.

- Dari pabrik Kediri $\left(\mathrm{P}_{2}\right)$ ke daerah A (Blitar) $8.288 .363 \mathrm{~kg}$.

- Dari pabrik Kediri $\left(\mathrm{P}_{2}\right)$ ke daerah C (Kediri) $4.861 .021 \mathrm{~kg}$.

- Dari pabrik Semarang $\left(\mathrm{P}_{3}\right)$ ke daerah B (Tulungagung) $5.705 .559 \mathrm{~kg}$.

- Dari pabrik Semarang $\left(\mathrm{P}_{3}\right)$ ke daerah C (Kediri) $2.102 .016 \mathrm{~kg}$.

- Dari pabrik Semarang $\left(\mathrm{P}_{3}\right)$ ke daerah E (Solo) $3.722 .637 \mathrm{~kg}$.

f. Metode MODI (Modified Distribution) berdasarkan tabel metode VAM (Vogel's Approximation Method), hasil biaya yang paling optimal adalah: Rp. 43.087.656.564,-.. Dengan kegiatan pendistribusian sebagai berikut :

- Dari pabrik Krian $\left(\mathrm{P}_{1}\right)$ ke daerah A (Blitar) $7.497 .770 \mathrm{~kg}$.

- Dari pabrik Krian $\left(\mathrm{P}_{1}\right)$ ke daerah D (Banyuwangi) $10.429 .782 \mathrm{~kg}$.

- Dari pabrik Kediri $\left(\mathrm{P}_{2}\right)$ ke daerah A (Blitar) $8.288 .363 \mathrm{~kg}$.

- Dari pabrik Kediri $\left(\mathrm{P}_{2}\right)$ ke daerah C (Kediri) $4.861 .021 \mathrm{~kg}$.

- Dari pabrik Semarang $\left(\mathrm{P}_{3}\right)$ ke daerah B (Tulungagung) $5.705 .559 \mathrm{~kg}$.

- Dari pabrik Semarang $\left(\mathrm{P}_{3}\right)$ ke daerah $\mathrm{C}$ (Kediri) 2.102.016 kg.

- Dari pabrik Semarang $\left(\mathrm{P}_{3}\right)$ ke daerah E (Solo) $3.722 .637 \mathrm{~kg}$.

\section{PENUTUP}

Pendistribusian produk pakan ternak di PT.X dengan menggunakan metode transportasi didapatkan hasil yang optimal. Total biaya transportasi untuk solusi awal menggunakan metode pojok kiri atas pojok kanan bawah (North West Corner Method) = Rp. 43.118.639.196,-; ongkos terkecil (Least Cost Method) = Rp. 43.094.262.979,-; VAM (Vogel's Approximation Method) = Rp. 43.089.578.434,- dan uji optimal menggunakan metode batu loncatan (Stepping Stone Method) dan MODI (Modified Distribution) didapatkan hasil yang optimal adalah : Rp. 43.087.656.564,--.

Pada penelitian di PT. $X$ dengan menggunakan metode transportasi, penggunaan metode yang tepat untuk mengoptimalkan biaya distribusi pakan ternak adalah untuk solusi fisibel awal menggunakan metode VAM (Vogel's Approximation Method) dengan hasil yang paling minimal diantara metode pojok kiri atas pojok kanan bawah, ongkos terkecil yaitu sebesar Rp. 43.089.578.434,- dan dilakukan uji optimalisasi menggunakan metode Stepping Stone Method dan MODI didapatkan biaya distribusi yang paling optimal adalah : Rp. 43.087.656.564,--.

Hasil dari pendistribusian produk yang telah dilakukan PT. X pada bulan Agustus 2010 sebesar Rp. 43.205.135.468,-. Sedangkan hasil perhitungan pendistribusian produk dengan metode transportasi sebesar Rp. 43.087.656.564,-. Dari analisa tersebut maka PT. X dapat mengoptimalkan biaya pendistribusian untuk bulan Agustus 2010 sebesar Rp. 117.478.904,--

Dalam mendapatkan biaya yang optimal dapat digunakan metode lain salah satunya adalah metode penugasan agar dalam hal ini lebih bisa mengetahui metode yang lebih baik dalam mengoptimalkan biaya pendistribusian atau biaya transportasi.

\section{DAFTAR PUSTAKA}

Ardhyani, I. W., \& Singgih, M. L. (2017). Pengukuran Kualitas Layanan dengan Higher Education Performance (HEdPERF) dan Higher Education Service Quality (HiEdQUAL). Teknika : Engineering and Sains Journal, 1(1), 25-32.

Dimyati, T. T., \& Dimyati, A. (1992). Operation Research dan Model-Model Pengambilan Keputusan (Edisi Kedua). Bandung : penerbit Sinar Baru Algesindo,.

Iskandar, J., \& Puji, A. (2001). Perencanaan dan Penjadwalan Produksi dengan Menggunakan Metode Transportasi Guna Meningkatkan Profit, Umm Scientific Journal, vol. 2.

Pangestu, S., et al. (1986). Dasar-Dasar Operations Research (Edisi Kedua). Yogyakarta : penerbit BPFE,.

Siagian P. (1987). Penelitian Operasional. Jakarta : penerbit Universitas Indonesia.

Supranto J. (1988). Riset Operasi Untuk Pengambilan Keputusan. Jakarta : penerbit Universitas Indonesia.

Swastha B. (1984). Azas - azas Marketing. Yogyakarta : penerbit Liberty.

Taha H., A. (1996). Riset Operasi Suatu Pengantar (Jilid I). Jakarta : penerbit Binarupa Aksara.

Tjiptono F. (1997). Strategi Pemasaran. Yogyakarta: penerbit Andi.

Yamit Z. (1997). Manajemen Kuantitatif Untuk Bisnis (Edisi Pertama). Yogyakarta : penerbit BPFE. 